regard to stroke risk, is the extent of atherosclerosis and calcification of the aortic arch vessels when choosing an alternative access strategy via the axillary, carotid, or innominate artery. We commend the authors on a very nice review of the topic, which continues to be of great interest and importance to the field.

\section{References}

1. Wyler von Ballmoos MC, Reardon MJ. Who should get surgical aortic valve replacement in the era of transcatheter aortic valve replacement? A surgeon's perspective. Ann Cardiothorac Surg. 2020;9:487-9.

2. Cribier A, Eltchaninoff H, Bash A, Borenstein N, Tron C, Bauer F, et al. Percutaneous transcatheter implantation of an aortic valve prosthesis for calcific aortic stenosis: first human case description. Circulation. 2002;106:3006-8.
3. Junquera L, Kalavrouziotis D, Dumont E, Rodés-Cabau J, Mohammadi S. Paradigm shifts in alternative access for transcatheter aortic valve replacement: an update. J Thorac Cardiovasc Surg. 2023;165:1359-70.e2.

4. Ivancev K, Vogelzang R. A 35 year history of stent grafting, and how EVAR conquered the world. Eur J Vasc Endovasc Surg. 2020;59:685-94.

5. Aquino A, Khiabani AJ, Henn MC, Zajarias A, Melby SJ, Sintek M, et al. Radiation exposure during transcatheter valve replacement: what cardiac surgeons need to know. Ann Thorac Surg. 2020;109:118-22.

6. Leon MB, Smith CR, Mack MJ, Makkar RR, Svensson LG, Kodali SK, et al. Transcatheter or surgical aortic-valve replacement in intermediate-risk patients. N Engl J Med. 2016;374:1609-20.

7. Reardon MJ, Van Mieghem NM, Popma JJ, Kleiman NS, Søndergaard L, Mumtaz M, et al. Surgical or transcatheter aortic-valve replacement in intermediate-risk patients. N Engl J Med. 2017;376:1321-31.

8. O'Hair DP, Bajwa TK, Popma JJ, Watson DR, Yakubov SJ, Adams DH, et al. Direct aortic access for transcatheter aortic valve replacement using a selfexpanding device. Ann Thorac Surg. 2018;105:484-90.

\title{
Commentary: An all-access pass to transcatheter aortic valve replacement
}

\section{Hellmuth R. Muller Moran, MD, Aaron J. Spooner, MD, MEHP, MMgt, FRCSC, and Michael H. Yamashita, MDCM, MPH, FRCSC}

From the first-in-man description by Cribier and colleagues in $2002^{1}$ to the most recently published guidelines on valvular heart disease in $2020,{ }^{2}$ transcatheter aortic valve replacement (TAVR) has evolved from a niche procedure to a standard intervention. This has revolutionized the treatment of aortic stenosis, but also produced several unanswered questions with regard to valve durability, subclinical leaflet thrombosis, permanent pacemaker insertion with subsequent rehospitalization, the evolving role of TAVR in low-risk patients, and preparing future cardiac surgeons for practices that include transcatheter techniques. ${ }^{3-5}$

\footnotetext{
From the Division of Cardiac Surgery, Department of Surgery, Max Rady College of Medicine, University of Manitoba, Winnipeg, Manitoba, Canada; and Cardiac Sciences Program, St Boniface Hospital, Winnipeg, Manitoba, Canada.

Disclosures: The authors reported no conflicts of interest.

The Journal policy requires editors and reviewers to disclose conflicts of interest and to decline handling or reviewing manuscripts for which they may have a conflict of interest. The editors and reviewers of this article have no conflicts of interest.

Received for publication May 3, 2021; revisions received May 3, 2021; accepted for publication May 4, 2021; available ahead of print May 7, 2021.

Address for reprints: Michael H. Yamashita, MDCM, MPH, FRCSC, Cardiac Sciences Program, St Boniface Hospital, Y3519-409 Tache Ave, Winnipeg, Manitoba, R2H 2A6 Canada (E-mail: myamashita@sbgh.mb.ca).

J Thorac Cardiovasc Surg 2023;165:1372-3

$0022-5223 / \$ 36.00$

Copyright (c) 2021 by The American Association for Thoracic Surgery

https://doi.org/10.1016/j.jtcvs.2021.05.006
}

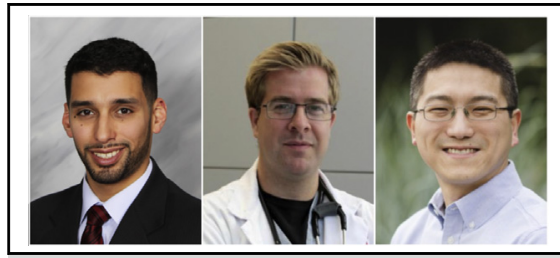

Hellmuth R. Muller Moran, MD, Aaron J. Spooner, MD, MEHP, MMgt, FRCSC, and Michael H. Yamashita, MDCM, MPH, FRCSC

\section{CENTRAL MESSAGE}

Many alternatives to transfemoral TAVR are available. Patient, operator, and institutional factors should be considered when deciding the optimal access route.

Naturally, although transfemoral TAVR (TF-TAVR) is the preferred route, questions surrounding the ideal alternative access have persisted for those patients not suitable for TF-TAVR.

Junquera and colleagues ${ }^{6}$ concisely and thoroughly review options for alternative access during TAVR. When available, they provide evidence comparing outcomes after each approach with TF-TAVR and with each other. The number of non-TF-TAVRs performed is not insignificant. Based on the most recent report of the Transcatheter Valve Therapy (TVT) Registry, nearly 3500 individuals underwent non-TF-TAVR in 2019 in the United States alone ( $\sim \%$ of TAVRs performed), whereas almost 27,500 patients have received non-TF-TAVR since the registry's 
inception in 2011. ${ }^{7}$ Thus, whereas the transfemoral approach continues to be the preferred method of TAVR, there is a substantial global need for expertise in alternative access. Certainly, favoring TF-TAVR at all costs is likely to be harmful in a reasonable number of patients.

As the authors describe, data on alternative access is inconclusive. They provide a useful decision-making algorithm synthesizing available evidence with reasonable suggestions based on patient-level factors. Yet, patientlevel factors represent only 1 potential aspect influencing the choice of access route. According to the TVT registry, the 72,991 individuals who underwent TAVR in 2019 were treated at 669 centers, with an average volume of approximately 109 individuals per center. ${ }^{7}$ Is it reasonable to expect the average TAVR center-performing 5 or fewer alternative access TAVRs per year-to replicate the same experience with alternative access as suggested by the literature? The same could be asked of centers with adequate experience and results using any 1 of the available alternative routes because the relationship between surgical volume and outcomes is well known. ${ }^{8}$ Obtaining appropriate vascular access and securing adequate closure are among the most commonly identified competencies related to transcatheter procedures, ${ }^{4}$ further emphasizing the importance of expertise in these procedural elements in both transfemoral and alternative access. ${ }^{3}$ The safety of any alternative route is therefore likely contingent on institutional and operator experience, with all forms of alternative access (including transthoracic) TAVR capable of being performed safely in experienced hands.
We congratulate the authors on an interesting and insightful review. This article will certainly be a useful reference for operators wishing to learn more about and possibly expand their use of alternative TAVR approaches. Cardiac surgeons are critical to obtaining excellent outcomes in alternative access TAVR and thus we should embrace the crucial role we play on multidisciplinary heart teams.

\section{References}

1. Cribier A, Eltchaninoff H, Bash A, Borenstein N, Tron C, Bauer F, et al. Percutaneous transcatheter implantation of an aortic valve prosthesis for calcific aortic stenosis: first human case description. Circulation. 2002;106:3006-8.

2. Otto CM, Nishimura RA, Bonow RO, Carabello BA, Erwin JP III, Gentile F, et al 2020 ACC/AHA guideline for the management of patients with valvular heart disease: a report of the American College of Cardiology/American Heart Association Joint Committee on clinical practice guidelines. Circulation. 2021;143: e72-227.

3. Muller Moran HR, Eikelboom R, Lodewyks C, Yan W, Zelentsov I, Arora RC, et al. Two-year outcomes from the PARTNER 3 trial: where do we stand? Curr Opin Cardiol. 2021;36:141-7.

4. Muller Moran HR, Maurice-Ventouris M, Alharbi M, Harley JM, Lachapelle KJ A scoping review to identify competencies for transcatheter cardiovascular procedures. J Thorac Cardiovasc Surg. 2020;165:1359-70.

5. Chamandi C, Barbanti M, Munoz-Garcia A, Latib A, Nombela-Franco L, Gutiérrez-Ibanez E, et al. Long-term outcomes in patients with new permanent pacemaker implantation following transcatheter aortic valve replacement. JACC Cardiovasc Interv. 2018;11:301-10.

6. Junquera L, Kalavrouziotis D, Dumont E, Rodés-Cabau J, Mohammadi S. Paradigm shifts in alternative access for transcatheter aortic valve replacement: an update. J Thorac Cardiovasc Surg. 2023;165:1359-70.e2.

7. Carroll JD, Mack MJ, Vemulapalli S, Herrmann HC, Gleason TG, Hanzel G, et al STS-ACC TVT Registry of Transcatheter Aortic Valve Replacement. J Am Coll Cardiol. 2020;76:2492-516.

8. Gonzalez AA, Dimick JB, Birkmeyer JD, Ghaferi AA. Understanding the volumeoutcome effect in cardiovascular surgery: the role of failure to rescue. JAMA Surg. 2014;149:119-23. 